\title{
Vermicomposting of Tofu Dregs and Cow Dung to Improve Nitrogen Availability and Growth of Bok Choy Plants
}

\section{Muhammad Rizon Affandi, Sri Nuryani Hidayah Utami* and Nugroho Susetya Putra}

Department of Soil Science, Faculty of Agriculture UGM, Jl Flora, Bulaksumur,

Yogyakarta, Indonesia

*Corresponding Author: Sri Nuryani Hidayah Utami, Department of Soil Science, Faculty of Agriculture UGM, Jl Flora, Bulaksumur, Yogyakarta, Indonesia.
Received: January 02, 2020

Published: January 28, 2020

(C) All rights are reserved by Sri Nuryani

Hidayah Utami., et al.

\begin{abstract}
This study aimed to determine the effect of tofu dregs combined with cow dung and the number of earthworms in vermicomposting on the growth of bok choy. The vermicomposting was carried out for 40 days. The total $\mathrm{N}$ content in vermicompost and soil was analyzed using the Kjeldahl method and the total $\mathrm{N}$ content in plant tissue using the wet destruction method with concentrated sulfuric acid and peroxide acid. The results showed that the combination of tofu dregs and cow dung significantly affected pH, DHL, water content, organic $\mathrm{C}$, total $\mathrm{N}$, available $\mathrm{N}$, and $\mathrm{C} / \mathrm{N}$ ratio of the vermicompost. Meanwhile, the number of earthworms significantly affected DHL, organic $\mathrm{C}$, total $\mathrm{N}$, available $\mathrm{N}$, and $\mathrm{C} / \mathrm{N}$ ratio. The effect of vermicompost application on the soil chemical properties was only seen on the total $\mathrm{N}$, while on the plant growth parameters was seen on the number of leaves, fresh weight, dry weight and $\mathrm{N}$ uptake of plants. The combination of organic matter sources and the number of earthworms, based on the chemical properties of vermicompost and their effect on the soil chemical properties and plant growth parameters, showed that the treatment of P5C2 (100\% cow dung and 10 earthworms) was the best combination in producing the highest content of vermicompost $\mathrm{N}$ and the plant weight as well as increasing $\mathrm{N}$ content in the soil.
\end{abstract}

Keywords: Cow Dung; Earthworm; N Uptake; Tofu Dregs; Vermicompost

\section{Introduction}

Organic matter is all matter coming from the recently living organisms. These materials can be in the form of crop residues and livestock manure, such as cow manure, chicken manure, and goat manure. All of these materials can release nutrients for the plants when they have undergone a decomposition process.

Cow dung is an organic matter that can be used as a source of nutrition for plants after a composting process. However, according to Kusumawati [1], one of the organic wastes that are not optimally used yet is livestock manure, especially cow dung. Whereas, animal (cattle) waste consisting of feces and urine, called manure, contain quite high organic matter, protein, and nutrients, which are good for microorganisms and certain animals and plants. Through composting, the waste can be managed to obtain organic fertilizer. Budiyanto [2] added that cow dung is one of the potential ingredients for organic fertilizer.

Other sources of organic matter are from industrial wastes. Food processing, such as tofu factory, in which the production process produces solid and liquid waste, the majority of which is underutilized. Many are also directly discharged into the environment (land and river), which can cause a decrease in environmental quality. One effort to overcome these problems is to manage the tofu waste through vermicomposting.
Vermicomposting is a process of organic matter decomposition, which involves collaboration between earthworms and microorganisms. Microorganisms that play a role in the process of vermicomposting are bacteria, fungi, and actinomycetes [3]. According to Hanafiah., et al. [4], earthworms are a type of soil macrofauna that can be used as bioameliorant of the soil because they can improve soil properties, such as nutrient availability, decomposition of organic matter, mineral weathering, aeration structure, aggregate formation, and drainage.

Earthworms have a very important role in the decomposition process of soil organic matter. The role of earthworms in the biogeochemical cycle also involves other soil microbes, especially bacteria. Roslim., et al. [5] state that earthworms are interested in animal dung containing a lot of $\mathrm{N}$, such as cow dung. Lumbricus sp. is known as litter feeders originating from Europe, which is now the most widely cultivated earthworm in Indonesia to be used as waste decomposer [6]. Soma (2009) added that Lumbricus sp. is a type of worm that has a higher speed of food consumption and reproduction when compared to other types of worms. These types of earthworms can adapt to various environmental conditions and remain in place as long as the food is available.

The authors are interested in the study on the effect of organic matter sources and their combination on the vermicomposting using Lumbricus rubellus earthworm. This study aimed to determine 
the best treatment and the optimum number of earthworms for organic matter decomposition for 40 days and to describe the effect of vermicompost on the growth of bok choy.

\section{Materials and Method}

This research was conducted from June to December 2017. The research was carried out in Pusat Studi Pengelolaan Sumberdaya Hayati (Center for Biological Resources Studies) UGM, greenhouse in Kuningan and the laboratories of Department of Soil Science, Faculty of Agriculture, Universitas Gadjah Mada, Yogyakarta.

\section{Tools and materials}

The research tools used were equipment for vermicomposting, equipment for planting bok choy in Kuningan greenhouse, tools for chemical and physical analysis in laboratories, destruction equipment, distillation equipment, muffle furnaces, soil Munsell color charts, sprayers, thermometers, analytical scales, soil sieve, $\mathrm{pH}$ meter, and EC meter.

The materials used in this study were tofu dregs taken from the Dongkelan tofu factory, Yogyakarta. Cow dung was taken from the Faculty of Animal Science, UGM, Yogyakarta. Lumbricus rubellus earthworms and soil samples were taken from Berbah, Sleman, Yogyakarta. Hybrid Gardena F1 bok choy seeds, chemicals for soil analysis, chemicals for vermicompost analysis, and chemicals for plant tissue analysis.

\section{Experimental design}

The experiment was arranged in a Completely Randomized Design (CRD) consisting of two factors. The first factor was the dose of tofu dregs and cow dung combination, and the second one was the population of Lumbricus rubellus. These two factors were combined, resulting in 10 treatment combinations with three replications so that 30 experimental units were obtained.

\section{Combination of tofu dregs and cow dung}

P1 $=25 \%$ tofu dregs: $75 \%$ cow dung

P2 $=50 \%$ tofu dregs: $50 \%$ cow dung

P3 $=75 \%$ tofu dregs: $25 \%$ cow dung

P4 $=100 \%$ tofu dregs: $0 \%$ cow dung

P5 $=0 \%$ tofu dregs: $100 \%$ cow dung

\section{Number of Earthworms:}

$\mathrm{C} 1$ = 5 earthworms

$\mathrm{C} 2=10$ earthworms

\section{Data analysis}

The research data were analyzed with analysis of variance using SAS software version 9.3 to see the significance of the influence of the factors. LSD test at 5\% was carried out to determine the difference between treatments.

\section{Results and Discussion}

Effectiveness of organic matter decomposition

The effectiveness value of organic matter decomposition describes the percentage of organic matter that can be decomposed within a certain period. Based on observations during the study (40 days), 1000 grams of organic matter obtained from cow dong showed the slowest decomposition, either with 5 or 10 earthworms. In contrast, 1000 grams of tofu dregs showed the fastest decomposition, while the combination showed slightly slower decomposition.

\begin{tabular}{|l|c|c|c|c|c|c|}
\hline \multirow{2}{*}{$\begin{array}{c}\text { Number of } \\
\text { earthworms }\end{array}$} & \multicolumn{7}{|c|}{ Tofu dregs: Cow dung } \\
\cline { 2 - 7 } & P1 & P2 & P3 & P4 & P5 & rata-rata \\
\hline C1 & 72.90 & 74.20 & 69.93 & 79.07 & 62.70 & $71.76 \mathrm{a}$ \\
\hline C2 & 75.37 & 75.53 & 77.80 & 81.90 & 64.90 & $75.10 \mathrm{a}$ \\
\hline Mean & $74.13 \mathrm{a}$ & $74.87 \mathrm{a}$ & $73.87 \mathrm{a}$ & $80.48 \mathrm{a}$ & $63.80 \mathrm{~b}$ & $(-)$ \\
\hline
\end{tabular}

Table 1: Percentage of the decomposed organic matter in various treatments.

Remarks: Means followed by the same letters in the same column or row are not significantly different according to LSD test at 5\%. (-) shows no interaction between factors.

The number of earthworms did not have a significant effect on the effectiveness of organic matter decomposition. About $80.48 \%$ of organic matter derived from $100 \%$ tofu waste (P4) was decomposed by earthworms, and the remaining $19.52 \%$ was still in its original structure. Meanwhile, $63.80 \%$ of organic matter derived from $100 \%$ cow dung (P5) was decomposed by earthworms. This result shows that the sequence of organic matter from tofu dregs is easier to be decomposed compared to that from cow dung. Tofu dregs have a finer particle size compared to cow dung, improving the eating ability of the earthworms. In the treatment of $100 \%$ tofu dregs, the decomposition of organic matter was faster than in other treatments because the more organic matter is eaten by earthworms, the more organic material is decomposed.

The texture of fibrous media can cause earthworms to have difficulty consuming the media [7]. Tofu dregs contain relatively small crude fiber ranging from 6\% [8] to 19.44\% [9]. Cow dung has a relatively dense texture and contains higher crude fiber so that the use of cow dung as an earthworm medium must be mixed with other ingredients to improve the media porosity, thereby facilitating the earthworms to consume the organic matter $[10,11]$. Based on these reviews, it can be concluded that the decomposition of organic matter in P1 (25\% tofu dregs and 75\% cow dung), P2 (50\% tofu dregs and 50\% cow dung) and P3 (75\% tofu dregs and 25\% cow dung) was higher than in P5, which was only cow dung.

\section{Chemical properties of vermicompost}

Based on the results of the study, the combination of tofu dregs and cow dung did not show better results compared to $100 \%$ tofu dregs or $100 \%$ cow dung. It can be seen from the maturity level of the vermicompost fertilizer indicated by the $\mathrm{C} / \mathrm{N}$ ratio. Tofu dregs (P4) and cow dung treatment produced a $\mathrm{C} / \mathrm{N}$ ratio value of 17.83 and 17.99 , respectively, in which a $\mathrm{C} / \mathrm{N}$ ratio below 20 indicates good fertilizer maturity.

Changes in acidity $(\mathrm{pH})$ indicate that the decomposition process is taking place. Differences in $\mathrm{pH}$ values in various treatments can occur due to biochemical processes during the composting 


\begin{tabular}{|l|c|c|c|c|c|}
\hline $\begin{array}{c}\text { Treatment Tofu } \\
\text { dregs: cow dung } \\
\text { (\%) }\end{array}$ & pH & $\begin{array}{c}\text { Water } \\
\text { content } \\
\text { (\%) }\end{array}$ & $\begin{array}{c}\text { Organic } \\
\text { matter } \\
\text { (\%) }\end{array}$ & $\begin{array}{c}\text { Organic } \\
\mathbf{C}(\%)\end{array}$ & $\begin{array}{c}\text { C/N } \\
\text { ratio }\end{array}$ \\
\hline P1 (25: 75) & 7.5 ab & $21.42 \mathrm{~b}$ & $50.77 \mathrm{ab}$ & $\begin{array}{c}25.39 \\
\mathrm{ab}\end{array}$ & $\begin{array}{c}19.61 \\
\mathrm{bc}\end{array}$ \\
\hline P2 (50: 50) & $7.9 \mathrm{a}$ & $24.98 \mathrm{ab}$ & $51.06 \mathrm{ab}$ & $\begin{array}{c}25.53 \\
\mathrm{ab}\end{array}$ & $\begin{array}{c}21.77 \\
\mathrm{ab}\end{array}$ \\
\hline P3 (75: 25) & $7.2 \mathrm{bc}$ & $21.47 \mathrm{~b}$ & $49.54 \mathrm{~b}$ & $24.77 \mathrm{~b}$ & $24.23 \mathrm{a}$ \\
\hline P4 (100: 0) & $7.1 \mathrm{c}$ & $23.38 \mathrm{ab}$ & $40.61 \mathrm{c}$ & $20.31 \mathrm{c}$ & $17.83 \mathrm{c}$ \\
\hline P5 (0: 100$)$ & $8.0 \mathrm{a}$ & $26.34 \mathrm{a}$ & $52.21 \mathrm{a}$ & $26.11 \mathrm{a}$ & $17.99 \mathrm{c}$ \\
\hline $\begin{array}{l}\text { Number of } \\
\text { earthworms }\end{array}$ & & & & & \\
\hline 5 & $7.5 \mathrm{p}$ & $23.78 \mathrm{p}$ & $51.15 \mathrm{p}$ & $25.58 \mathrm{p}$ & $23.31 \mathrm{p}$ \\
\hline 10 & $7.6 \mathrm{p}$ & $23.25 \mathrm{p}$ & $46.52 \mathrm{q}$ & $23.26 \mathrm{q}$ & $17.25 \mathrm{q}$ \\
\hline Interaction & $(-)$ & $(-)$ & $(-)$ & $(-)$ & $(-)$ \\
\hline CV & 4.95 & 15.04 & 3.38 & 3.38 & 11.31 \\
\hline
\end{tabular}

Table 2: Effect of organic matter sources and number of earthworms on the value of $\mathrm{pH}$, water content (\%), organic matter (\%), organic carbon (\%), and $\mathrm{C} / \mathrm{N}$ ratio of vermicompost produced.

Remarks: Means followed by the same letters in the same column are not significantly different according to LSD test at 5\%. (-) shows no interaction between factors.

process. The decrease in $\mathrm{pH}$ occurs due to the release of organic acids, while the increase in $\mathrm{pH}$ occurs due to the release of $\mathrm{NH} 3$ from nitrogen compounds and the release of base cations from the mineralization process. The changes in $\mathrm{pH}$ can also occur due to microbial activity in organic matter decomposition [11].

The decrease in water content in various treatments can be caused by the evaporation of water during the composting process. Evaporation of water occurs because of the release of energy in the form of heat by the activity of thermophilic bacteria decomposing the organic matter. Therefore, when the media experiences an exothermic reaction causing heat, the water content of the organic matter evaporates and decreases [12]. Based on the analysis of variance and posthoc tests (LSD 5\%), the water content in all treatments was quite low. This result is supported by Diaz [13], stating that at the end of the composting process, the water content must be low enough (around 30\%) to prevent continued biological activity on stable compost material.

The physical properties of organic matter affect the process of its decomposition. Tofu dregs have smaller crude fiber content compared to cow dung. Besides, the organic matter texture of tofu dregs is finer, whereas that of cow dung is coarser and denser. The more organic matter decomposed by earthworms and microbes, the faster the decomposition process. It can occur because of the release of complex carbon chain bonds into simpler bonds due to the $\mathrm{C}$ element used by organisms to obtain energy for their living needs so that the carbon content in vermicompost will be lower than the initial organic matter.

The vermicompost produced from the decomposition by ten earthworms has the highest maturity (lowest $\mathrm{C} / \mathrm{N}$ ) with a ratio of 17.25. In general, the $\mathrm{C} / \mathrm{N}$ ratio of vermicompost produced by five earthworms has a higher ratio of more than 20 . This result shows that five earthworms have not been able to decompose the organic matter within 40 days completely. Besides, there is also possibly less microorganism activity. According to Gaur [14], a high C/N ratio indicates that the media has high $\mathrm{C}$ levels and low $\mathrm{N}$. Tisdale and Nelson [15] add that $\mathrm{C} / \mathrm{N}$ ratio less than 20 indicates the occurrence of $\mathrm{N}$ mineralization and greater than 30 indicates immobilized N. Meanwhile, C/N ratio between 20-30 means that the mineralization is balanced with immobilization.

\section{Nitrogen content in vermicompost}

Vermicompost from $100 \%$ cow dung (P5) has the highest total $\mathrm{N}$ content of $1.48 \%$, while the highest ammonium $\left(\mathrm{NH}^{4+}\right)$ content is produced by vermicompost from 500 grams of tofu dregs and 500 grams of cow dung (P2) with a value of $0.17 \%$. The highest nitrate content was observed in vermicompost from 1000 grams of tofu dregs (P4), which has a $\mathrm{NO}^{3-}$ content of $0.20 \%$ and is not significantly different from 1000 grams of cow dung (P5) which is $0.19 \%$. Tofu dregs have a higher protein content than cow dung but produce vermicompost with lower $\mathrm{N}$ levels. This result can occur because the protein compounds in tofu dregs may be more complex, so the breakdown of nitrogen compounds into organic $\mathrm{N}$ and available nitrogen is relatively longer.

\begin{tabular}{|l|c|c|c|}
\hline $\begin{array}{c}\text { Treatment Tofu } \\
\text { dregs: Cow dung (\%) }\end{array}$ & Total N (\%) & $\begin{array}{c}\text { N-NH } \\
\text { (\%) }\end{array}$ & $\begin{array}{c}\text { N-NO } \\
\text { (\%) }\end{array}$ \\
\hline P1 (25: 75) & $1.31 \mathrm{~b}$ & $0.154 \mathrm{~b}$ & $0.178 \mathrm{ab}$ \\
\hline P2 (50: 50) & $1.19 \mathrm{bc}$ & $0.174 \mathrm{a}$ & $0.176 \mathrm{ab}$ \\
\hline P3 (75: 25) & $1.05 \mathrm{c}$ & $0.169 \mathrm{ab}$ & $0.158 \mathrm{~b}$ \\
\hline P4 (100: 0) & $1.17 \mathrm{bc}$ & $0.168 \mathrm{ab}$ & $0.195 \mathrm{a}$ \\
\hline P5 (0: 100) & $1.48 \mathrm{a}$ & $0.168 \mathrm{ab}$ & $0.185 \mathrm{a}$ \\
\hline Number of earthworms & & & \\
\hline 5 & $1.12 \mathrm{q}$ & $0.155 \mathrm{q}$ & $0.162 \mathrm{q}$ \\
\hline 10 & $1.36 \mathrm{p}$ & $0.179 \mathrm{p}$ & $0.195 \mathrm{p}$ \\
\hline Interaction & $(-)$ & $(-)$ & $(-)$ \\
\hline CV & 10.16 & 9.13 & 10.49 \\
\hline
\end{tabular}

Table 3: Effect of organic matter sources and number of earthworms on the content of total $\mathrm{N}, \mathrm{N}-\mathrm{NH}_{4}$ (ammonium), and $\mathrm{N}-\mathrm{NO}_{3}$ (nitrate) in the vermicompost produced.

Remarks: Means followed by the same letters in the same column are not significantly different according to LSD test at 5\%. (-) shows no interaction between factors.

Differences in nitrogen content in vermicompost produced can occur due to the presence of mineralization producing organic $\mathrm{N}$, ammonium and nitrate, immobilization by microorganisms, and the presence of volatilization and leaching of the nitrogen element. High total $\mathrm{N}$ content in the treatment is due to the high $\mathrm{N}$ content in media and the addition of nitrogen excreted by earthworms or microbes. Meanwhile, the consumption of nitrogen by worms and microbes, which is higher than the release of nitrogen, will reduce the $\mathrm{N}$ content in the vermicompost produced.

High ammonium content is due to the addition of ammonium excreted by earthworms and microbes, while the lower ammonium content is possibly due to the lower rate of ammonium excre- 
tion by earthworms compared to the rate of ammonium converted into nitrates by Nitrobacter. Low nitrate content in vermicompost is possible because the conversion of nitrate $\left(\mathrm{NO}_{3+}\right)$ to nitrite $\left(\mathrm{N}_{2}\right)$ is faster. The high nitrate content can be due to the slower process of nitrification and the activity of microorganisms converting organic $\mathrm{N}$ into ammonium and nitrate.

Overall, vermicompost produced has a higher nitrate content than ammonium content. This result can occur because of the mucus in organic matter due to the activity of earthworms when consuming and decomposing the organic matter. The mucus produced by the earthworm contains a lot of Nitrobacter so that the nitrification process in the form of nitrate is more likely to occur, which increases nitrate content in the vermicompost produced. This result was supported by Atiyeh., et al. [16], stating that several studies have found that the content of available nitrogen in conventional compost was higher in ammonium, whereas vermicompost tends to be higher in nitrates.

Vermicompost from the decomposition of organic matter by ten earthworms produced higher total $\mathrm{N}$ levels (1.36\%), ammonium $(0.18 \%)$, and nitrate $(0.20 \%)$ compared to the vermicompost from organic matter decomposed by five earthworms showing the values of $1.12 \%, 0.16 \%$, and $0.16 \%$, respectively. According to Tripathi and Bhardwaj [17], earthworms can increase $\mathrm{N}$ content in vermicompost through the results of excretion of ammonia, nitrogenase enzymes, and mucous fluid. Lol., et al. [12] and Joseph [11] added that the high nutrient content in vermicomposts was thought to originate from the digestion and mineralization of organic matters containing nutrients in high concentrations.

\section{Soil chemical properties after harvest}

An analysis of initial soil properties was performed to determine soil conditions before treatment. Based on the results of the analysis, the soil pH is 5.7, which is, according to Balittanah (2009), slightly acidic. The initial soil EC is $0.004 \mathrm{dS} / \mathrm{m}$, is included in the low category (Balittanah, 2009). The soil has low content of organic carbon $(0.82 \%)$, low CEC (7.21), and low content of total $\mathrm{N}$ $(0.14 \%)$. The soil consists of $76 \%$ sand fraction, $20 \%$ dust fraction, and only $4 \%$ clay fraction, indicating that the soil is classified in loamy sand.

Analysis of the soil after harvest was performed to determine the effect of vermicompost application on the soil chemical properties. Based on the results of the analysis of variance and posthoc test (LSD 5\%), there was a significant improvement in the soil chemical properties after harvest compared to the soil chemical properties before treatment. Soil pH after treatment was higher (7.1-7.4) than soil $\mathrm{pH}$ before treatment (5.7). The vermicompost application increased the soil $\mathrm{pH}$, which was originally slightly acidic to neutral to slightly alkaline. The increase in $\mathrm{pH}$ occurs due to the process of organic matter decomposition in vermicompost, producing base cations so that they contribute to $\mathrm{OH}$ - in the soil. Besides, an increase in $\mathrm{pH}$ can occur due to the release of $\mathrm{NH}_{3}$ from nitrogen compounds. Hanafiah [18] states that base cations are cations that, if reacted with water, will produce $\mathrm{OH}$ - ions, thereby increasing the soil $\mathrm{pH}$.

\begin{tabular}{|l|l|l|l|l|l|}
\hline $\begin{array}{c}\text { Treatment } \\
\text { Tofu dregs: } \\
\text { Cow dung (\%) }\end{array}$ & $\mathbf{p H}$ & $\begin{array}{c}\text { EC } \\
\mathbf{( d S / m )}\end{array}$ & $\begin{array}{c}\text { Organic } \\
\mathbf{C}(\%)\end{array}$ & $\begin{array}{c}\text { CEC(cmol } \\
\mathbf{( + ) / k g )}\end{array}$ & $\begin{array}{c}\text { Total N } \\
(\%)\end{array}$ \\
\hline P1 (25: 75) & $7.4 \mathrm{a}$ & $0.018 \mathrm{a}$ & $2.22 \mathrm{a}$ & $7.66 \mathrm{a}$ & $0.21 \mathrm{~b}$ \\
\hline P2 (50: 50) & $7.1 \mathrm{a}$ & $0.015 \mathrm{a}$ & $2.28 \mathrm{a}$ & $7.83 \mathrm{a}$ & $\begin{array}{c}0.25 \\
\mathrm{ab}\end{array}$ \\
\hline P3 (75: 25) & $7.2 \mathrm{a}$ & $0.015 \mathrm{a}$ & $2.24 \mathrm{a}$ & $7.53 \mathrm{a}$ & $0.23 \mathrm{~b}$ \\
\hline P4 (100: 0) & $7.1 \mathrm{a}$ & $0.017 \mathrm{a}$ & $2.13 \mathrm{a}$ & $8.01 \mathrm{a}$ & $0.21 \mathrm{~b}$ \\
\hline P5 (0: 100) & $7.2 \mathrm{a}$ & $0.016 \mathrm{a}$ & $2.43 \mathrm{a}$ & $8.37 \mathrm{a}$ & $0.28 \mathrm{a}$ \\
\hline $\begin{array}{l}\text { Number of } \\
\text { earthworms }\end{array}$ & & & & & \\
\hline 5 & $7.2 \mathrm{p}$ & $0.014 \mathrm{q}$ & $1.66 \mathrm{p}$ & $7.86 \mathrm{p}$ & $0.25 \mathrm{p}$ \\
\hline 10 & $7.2 \mathrm{p}$ & $0.018 \mathrm{p}$ & $2.86 \mathrm{p}$ & $7.90 \mathrm{p}$ & $0.23 \mathrm{p}$ \\
\hline Treatment & $7.2 \mathrm{a}$ & $0.016 \mathrm{a}$ & $1.64 \mathrm{a}$ & $7.88 \mathrm{a}$ & $0.24 \mathrm{a}$ \\
\hline Control & $6.9 \mathrm{a}$ & $0.008 \mathrm{~b}$ & $0.98 \mathrm{~b}$ & $7.14 \mathrm{a}$ & $0.15 \mathrm{~b}$ \\
\hline Interaction & $(-)$ & $(-)$ & $(-)$ & $(-)$ & $(-)$ \\
\hline CV & 2.91 & 32.14 & 11.78 & 20.29 & 15.06 \\
\hline
\end{tabular}

Table 4: Effect of vermicompost produced on the soil chemical properties after harvest.

Remarks: Means followed by the same letters superscript in the same column are not significantly different according to LSD test at $5 \%$. (-) shows no interaction between factors.

The value of soil CEC showed an increase after harvest, with values ranging from 0.015 to $0.018 \mathrm{dS} / \mathrm{m}$, compared to the initial soil $(0.004 \mathrm{dS} / \mathrm{m})$. The increase occurs because of the release of electrically weak nutrient cations due to the addition of vermicompost containing organic material, which will also experience mineralization. The mineralization process will also release organic N, ammonium, and nitrate so that it will increase nitrogen content in the soil, which was in this study, increased from $0.14 \%$ to $0.21-0.28 \%$.

The addition of vermicompost also increased soil CEC due to the organic colloids contributed by the organic matter, in the form of humus, resulted from humification. The negative charge produced by humus can bind cations in the soil and allow the cations exchange to increase, increasing soil CEC even though the increase is not quite high. Soil organic carbon after harvest increased from $0.82 \%$ to $2.13 \%-2.43 \%$. The vermicompost application significantly increased the organic carbon content of the soil. This result can be due to the decomposed organic matter in vermicompost, producing organic $\mathrm{C}$, thereby increasing organic carbon content in the soil. Besides, it is also possibly caused by the faster decomposition process of organic matter due to the abundant microbial activity in vermicompost.

\section{Growth of bok choy plants}

Plant height is an indicator commonly observed in plant growth. Plant height is sensitive to environmental factors, one of which is sunlight. The application of vermicompost significantly increased the average plant height, reaching $11.76 \mathrm{~cm}$. However, the observations showed that both the combination of organic matter sources and the number of earthworms in vermicomposting did not significantly affect plant height. 
The growth of bok choy plants is also characterized by the increasing number of leaves. Sitompul and Guritno [19] stated that leaves, in general, are the main organs producing photosynthates. Observation of the number of leaves is needed as one indicator of growth that can explain the process of plant growth. Leaf observation can be based on the function of the leaves in photosynthesis. Based on the results of the study, there was no interaction effect between organic matter sources and the number of earthworms on the number of leaves. However, the application of vermicompost from $100 \%$ cow dung (P5) significantly increased the number of leaves, producing the highest number of leaves of 16 leaves. Meanwhile, the vermicompost from $25 \%$ tofu dregs and $75 \%$ cow dung resulted in the lowest number of leaves. On the contrary, there was no significant effect of the number of earthworms on the number of leaves.

\begin{tabular}{|l|c|c|}
\hline $\begin{array}{c}\text { Treatment Tofu dregs: } \\
\text { Cow dung (\%) }\end{array}$ & $\begin{array}{c}\text { Plant Height } \\
\text { (cm) }\end{array}$ & $\begin{array}{c}\text { Number of } \\
\text { Leaves }\end{array}$ \\
\hline P1 (25: 75) & $10.89 \mathrm{a}$ & $14.00 \mathrm{~b}$ \\
\hline P2 (50: 50) & $12.63 \mathrm{a}$ & $15.00 \mathrm{ab}$ \\
\hline P3 (75: 25) & $11.59 \mathrm{a}$ & $14.34 \mathrm{~b}$ \\
\hline P4 (100: 0) & $12.92 \mathrm{a}$ & $15.00 \mathrm{ab}$ \\
\hline P5 (0: 100) & $10.77 \mathrm{a}$ & $16.00 \mathrm{a}$ \\
\hline Number of earthworms & & \\
\hline 5 & $11.57 \mathrm{p}$ & $14.94 \mathrm{p}$ \\
\hline 10 & $11.94 \mathrm{p}$ & $14.80 \mathrm{p}$ \\
\hline Treatment & $11.76 \mathrm{a}$ & $14.87 \mathrm{a}$ \\
\hline Control & $08.33 \mathrm{~b}$ & $13.00 \mathrm{~b}$ \\
\hline Interaction & $(-)$ & $(-)$ \\
\hline CV & 16.63 & 19.43 \\
\hline
\end{tabular}

Table 5: Effect of vermicompost produced on the average plant height and number of leaves $t$.

Remarks: Means followed by the same letters superscript in the same column are not significantly different according to LSD test at $5 \%$. (-) shows no interaction between factors.

The application of vermicompost showed a better plant height response than the control treatment. This result shows that the provision of vermicompost can increase plant growth by providing nutrients for plants. According to Manivannan., et al. [20], improvements in plant growth and yield due to the application of vermicompost are due to the improvement in soil quality and availability of micro and macronutrients, as well as the increase in soil microbial activity. The results of the study of Alribowo., et al. [21] also showed that bok choy plants treated with vermicompost at 10 tons/ha had an average plant height of $12.03 \mathrm{~cm}$ higher than the average height of bok choy plants without the provision of fertilizer, which was $9.54 \mathrm{~cm}$.

Nitrogen is the basic ingredient to form amino acids and proteins that will be used for plant metabolic processes [22]. Plant metabolism is running well with the sufficient availability of $\mathrm{N}$ so that the plant roots will absorb nutrients needed by plants, increasing the number of plant leaves. A similar opinion was conveyed by
Brady and Buckman [23], who stated that the nitrogen element is beneficial for vegetative growth of plants, particularly forming new cells such as in leaves and branches and renewing damaged cells. Zahid [24] reported that the addition of vermicompost played an important role in leaf formation.

The application of vermicompost significantly increased the average number of bok choy leaves compared to control treatment. The increase in the number of leaves is because vermicompost provides nutrients that can stimulate the vegetative growth of plants. According to Wijaya [25], the nitrogen element is an essential macro element that plays a major role as a constituent of plant body components such as protein, enzymes, hormones, and chlorophyll. Salisbury and Ross [26] added that N nutrients were needed by plants in stimulating vegetative growth, which is in line with the opinion of Jumin [27], stating that $\mathrm{N}$ functions included increasing vegetative growth, especially the number of leaves.

\section{Crop weight of bok choy}

The fresh weight of bok choy indicates the water content contained in the plants, while the dry weight indicates the accumulation of assimilates resulted from plant activity. According to Salisbury and Ross [26], the fresh weight of plants is not only consisted of water but also nutrient uptake. If the newly harvested plant parts are heated at $70-80^{\circ} \mathrm{C}$, almost all of the water will evaporate. The effect of vermicompost application on the average fresh weight (FW) and dry weight (DW) of bok choy can be seen in table 6 .

\begin{tabular}{|l|c|c|}
\hline $\begin{array}{c}\text { Treatment Tofu dregs: } \\
\text { Cow dung (\%) }\end{array}$ & $\begin{array}{c}\text { Fresh Weight } \\
\text { (g) }\end{array}$ & $\begin{array}{c}\text { Dry Weight } \\
\text { (g) }\end{array}$ \\
\hline P1 (25: 75) & $55.33 \mathrm{c}$ & $3.75 \mathrm{~b}$ \\
\hline P2 (50: 50) & $68.42 \mathrm{ab}$ & $4.38 \mathrm{ab}$ \\
\hline P3 (75: 25) & $67.93 \mathrm{ab}$ & $4.08 \mathrm{~b}$ \\
\hline P4 (100: 0) & $55.88 \mathrm{bc}$ & $3.82 \mathrm{~b}$ \\
\hline P5 (0: 100) & $76.20 \mathrm{a}$ & $4.93 \mathrm{a}$ \\
\hline Number of Earthworms & & \\
\hline 5 & $64.18 \mathrm{p}$ & $4.17 \mathrm{p}$ \\
\hline 10 & $65.33 \mathrm{p}$ & $4.22 \mathrm{p}$ \\
\hline Treatment & $64.75 \mathrm{a}$ & $4.19 \mathrm{a}$ \\
\hline Control & $29.77 \mathrm{~b}$ & $2.13 \mathrm{~b}$ \\
\hline Interaction & $(-)$ & $(-)$ \\
\hline CV & 16.12 & 15.87 \\
\hline
\end{tabular}

Table 6: Effect of vermicompost produced on the average weight of bok choy.

Remarks: Means followed by the same letters in the same column are not significantly different according to LSD test at 5\%. (-) shows no interaction between factors.

The application of vermicompost from 100\% cow dung (P5) treatment produced the highest crop weight, consisting of a fresh weight of 76.20 grams and a dry weight of 4.93 grams. This result is due to the sufficient nutrients provided by the vermicompost resulted from 100\% cow dung (P5), encouraging physiological and metabolic processes, thereby increasing the fresh weight. The 
increase occurs because of an increase in weight and volume due to cell lengthening and enlargement. Cell size increases due to the presence of sufficient nitrogen so that it stimulates the formation of the auxin hormone resulting in the softening of the cell wall followed by increased ability to process water uptake in the soil.

The average crop weight of bok choy treated with vermicompost was higher compared to the crop weight of control plants. The application of vermicompost resulted in a fresh weight of 64.75 grams and a dry weight of 4.19 grams. Meanwhile, the average fresh and dry weight of the control plants (without vermicompost) was 29.77 and 2.13 grams, respectively. The crop weight of bok choy given vermicompost is better because of the provision of nutrients needed by plants during their growth so that it affects plant metabolism. Better the metabolic process leads to better the plant's ability to absorb water and nutrients in the soil. Mahmoud and Ibrahim [28] added that vermicompost application could improve soil chemical properties and availability of N, P, and K in the soil.

The application of vermicompost from $100 \%$ cow dung (P5) resulted in the highest dry weight because it had the highest average number of leaves (Table 5), thereby increasing the photosynthesis rate. A similar opinion was conveyed by Hamim [29], stating that more leaves allow more photosynthesis to occur. Increased photosynthesis will produce more photosynthate, consequently, increasing the dry weight, and the photosynthetic energy produced is used to form and maintain leaf quality. This result is supported by Harjadi [30], stating that the leaves are the organs producing dry matter.

\section{Nitrogen Uptake by Plants}

The average total $\mathrm{N}$ content in the bok choy plants treated with vermicompost was higher $(7.31 \%)$ compared to the average total $\mathrm{N}$ content in control plants (3.66\%). The application of vermicompost from $100 \%$ cow dung (P5) resulted in the highest total $\mathrm{N}$ content in plant tissues with a value of $7.64 \%$. However, this value is not significantly different from the values in other treatments.

Better response to the treatment, compared to control, is due to the application of vermicompost, which provides nutrients for plants. Besides, it is also enhanced by the decomposition of organic matter in vermicompost, followed by the release of available nitrogen from the mineralization process, and nitrogen uptake by plants. The high response of bok choy to nitrogen can be related to the status of soil fertility in the planting medium used, where the nitrogen content in the media is relatively low. This result is supported by Winaya [31], stating that the lower soil fertility leads to a higher plant response to fertilization.

The nitrogen uptake was calculated to determine the uptake of $\mathrm{N}$ elements by plants during the growth period. The highest $\mathrm{N}$ uptake was found in plants treated with vermicompost from 100\% cow dung (P5), which was 0.38 gram/plant. The application of vermicompost from various organic matter sources showed different $\mathrm{N}$ uptake responses. These conditions correlate with total $\mathrm{N}$ content in the soil after vermicompost application (total $\mathrm{N}$ content in

\begin{tabular}{|l|c|c|}
\hline $\begin{array}{c}\text { Treatment Tofu } \\
\text { dregs: Cow dung (\%) }\end{array}$ & $\begin{array}{c}\text { N content in plant } \\
\text { tissues (\%) }\end{array}$ & $\begin{array}{c}\text { N uptake } \\
\text { (g/plant) }\end{array}$ \\
\hline P1 (25: 75) & $7.25 \mathrm{a}$ & $0.27 \mathrm{~b}$ \\
\hline P2 (50: 50) & $7.07 \mathrm{a}$ & $0.31 \mathrm{ab}$ \\
\hline P3 (75: 25) & $7.28 \mathrm{a}$ & $0.30 \mathrm{~b}$ \\
\hline P4 (100: 0) & $7.28 \mathrm{a}$ & $0.28 \mathrm{~b}$ \\
\hline P5 (0: 100) & $7.64 \mathrm{a}$ & $0.38 \mathrm{a}$ \\
\hline Number of Earthworms & & \\
\hline 5 & $7.16 \mathrm{p}$ & $0.30 \mathrm{p}$ \\
\hline 10 & $7.45 \mathrm{p}$ & $0.31 \mathrm{p}$ \\
\hline Treatment & $7.31 \mathrm{a}$ & $0.31 \mathrm{a}$ \\
\hline Control & $3.66 \mathrm{~b}$ & $0.08 \mathrm{~b}$ \\
\hline Interaction & $(-)$ & $(-)$ \\
\hline CV & 6.76 & 19.43 \\
\hline
\end{tabular}

Table 7: Effect of vermicompost produced on the nitrogen content (\%) in plant tissues and nitrogen uptake (g/plant) of bok choy plants.

Remarks: Means followed by the same letters in the same column are not significantly different according to LSD test at 5\%. (-) shows no interaction between factors.

Table 4). The relationship of total $\mathrm{N}$ content in the soil and plant $\mathrm{N}$ uptake can be seen in figure 1.

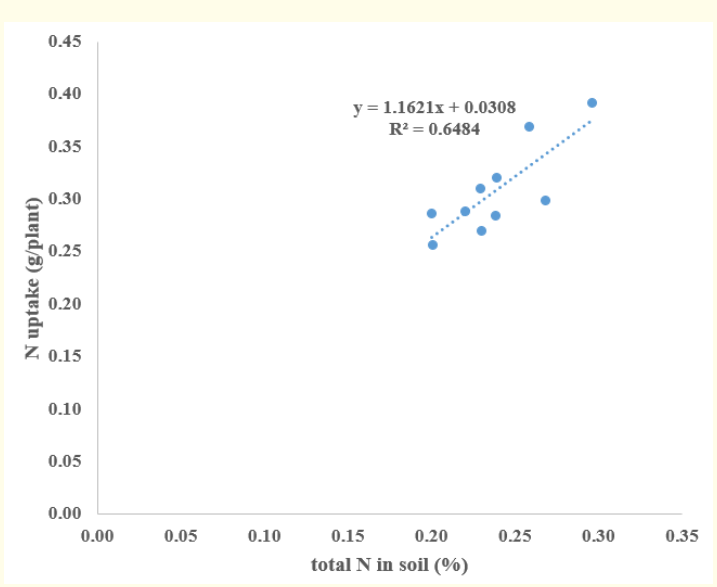

Figure 1: Relationship between total $\mathrm{N}$ in the soil and $\mathrm{N}$ uptake by bok choy plants

The graph of the relationship between total $\mathrm{N}$ content in the soil and plant $\mathrm{N}$ uptake in Figure 1 shows a positive correlation with an $\mathrm{R} 2$ of 0.65 or R-value of 0.82 , which means that $\mathrm{N}$ content in the soil has a strong influence on plant $\mathrm{N}$ uptake. This result shows that the higher the $\mathrm{N}$ uptake of plants indicates the higher content of $\mathrm{N} \mathrm{nu}-$ trients in the soil. The vermicompost resulted from various treatments had different $\mathrm{N}$ levels, thus affecting the $\mathrm{N}$ content in the soil, which also affects the $\mathrm{N}$ uptake of plants. According to Rosmarkam and Yuwono [32], organic matter in the mineralization process will release nutrients. Hanafiah [18] added that ammonium and nitrate from mineralization, if not accumulated by plants or microbes, can be lost through leaching or volatilization in the form of gas. 
Table 7 shows that the application of vermicompost has a significantly different effect on $\mathrm{N}$ uptake of bok choy plants compared to control. The application of vermicompost resulted in the higher $\mathrm{N}$ uptake (0.31 gram/plant) compared to that of control $(0.08$ gram/ plant). According to Soepardi [33], nutrient uptake by plants is strongly influenced by the levels and availability of nutrients in the soil. As shown in Table 4, the soil treated with vermicompost has a total $\mathrm{N}$ content of $0.24 \%$, which is higher than in the soil without vermicompost $(0.15 \%)[34,35]$.

\section{Conclusion}

1. N content in vermicompost produced from various treatment combinations ranges from $0.92 \%-1.65 \%$.

2. The use of organic matter sources of $1000 \mathrm{~g}$ of cow dung (P5) combined with the addition of 10 earthworms (C2) produces the best vermicompost which has content of total $\mathrm{N} 1.65 \%, \mathrm{~N}-\mathrm{NH}_{4}$ of $0.19 \%, \mathrm{~N}-\mathrm{NO}_{3}$ of $0.22 \%$, organic $\mathrm{C}$ of $25.38 \%$ and the $\mathrm{C} / \mathrm{N}$ ratio of 15.37 .

3. The application of vermicompost from 1000 grams of cow dung (P5) has the best effect on increasing total N-soil content, number of leaves, harvest weight, and N uptake of bok choy plants.

\section{Acknowledgement}

This research was supported by Faculty Pertanian Universitas Gadjah Mada Research Grant (contract number 2374/PN/ TU/2018) chaired by Dr.Ir. Sri Nuryani Hidayah Utami. The authors would like to thank for the supporting.

\section{Bibliography}

1. Kusumawati N. "Evaluasi perubahan temperature $\mathrm{pH}$ dan kelembaban media pada pembuatan vermikompos dari campuran jerami padi dan kotoran sapi menggunakan Lumbricus rubellus". Inotek 15 (2011): 45-56.

2. Budiyanto K. “Tipologi Pendayagunaan Kotoran Sapi dalam Upaya Mendukung Pertanian Organik di Desa Sumbersari Kecamatan Poncokusumo Kabupaten Malang". Journal GAMMA 7 (2011): 42-49.

3. Dominguez J., et al. "A Comparation of Vermikomposting and Composting". Bio Cycle 38 (1997): 57-59.

4. Hanafiah KA., et al. Biologi Tanah: Ekologi Makrobiologi Tanah. PT Raja Grafindo Persada. Jakarta (2005).

5. Roslim DI., et al. "Karakter morphologi dan pertumbuhan tiga jenis cacing tanah lokal Pekanbaru pada dua macam media pertumbuhan". Biosaintifika: Journal of Biology and Biology Education 5 (2013): 1-9.

6. Listyawan B., et al. Teknologi VAP-BL. PT Vermi Alam Prima Lestari. Bandung (1998).

7. Erni F. "Pengaruh penggunaan feses sapi dan campuran limbah organik sebagai pakan atau media terhadap produksi kokon dan biomasa cacing tanah Eisenia foetida savigny". Fakultas Peternakan. IPB. Skripsi (2000).
8. Anggoro R. "Ilmu Makanan Ternak Unggas”. Kemajuan Mutakhir. UI Press. Jakarta (1985).

9. Suprapti ML. Aneka Olahan Pisang. Kanisius. Yogyakarta (2005).

10. Gaddie RE and DE Douglas. Earthworm for Ecology and Profit. Bookworm Publishing Company Ontario. California 2 (1977).

11. Joseph PV. "Efficacy of Different Substrates on vermicompost Production: A Biochemical Analysis" (2019).

12. Lol TC., et al. "Vermicomposting of cattle and goat manure by Eisenia fetiga and their growth reproduction performance". Bioresource Technology 96 (2005): 111-114.

13. Diaz LF. “Compost Science and Technology”. Elsevier Waste Management Series (2007).

14. Gaur AC. A manual of rural composting improving soil fertility through organik recycling. Project Field Document No. 15 FAO. New Delhi. India (1982).

15. Tisdale SL and WL Nelson. Soil Fertility and Fertilizers. Macmillan Publishing. London (1975).

16. Atiyeh RM., et al. "Effects of vermi-composts and composts on plant growth in horticultural container media and soil". Pedobiologia 44.5 (2000): 579-590.

17. Tripathi G and P Bhardwaj. "Decomposition of kitchen waste amended with cow manure using epigeic spesies (Eisenia foetida) and anecic species (Lampito mauritii)". Bioresource Technology 92 (2004): 215-218.

18. Hanafiah KA. Dasar-dasar Ilmu Tanah. Raja Grafindo Persada. Jakarta (2014).

19. Sitompul SM and dan B Guritno. Analisis Pertumbuhan Tanaman. UGM Press. Yogyakarta (1995).

20. Manivannan S., et al. "Effect of vermicompost on soil fertility and crop productivity beans (Phaseolusvulgaris)". Journal of Environmental Biology 30 (2009): 275-81.

21. Alribowo., et al. "Pengaruh pemberian vermikompos terhadap pertumbuhan dan produksi pakchoy (Brassica rapa L.)”. JOM Faperta 3.2 (2016): 1-9.

22. Lakitan B. Dasar-Dasar Fisiologi Tumbuhan. Raja Grafindo Persada. Jakarta (2011).

23. Brady $\mathrm{N}$ and H Buckman. Ilmu Tanah. Bhratara Karya Aksara. Jakarta (1982).

24. Zahid A. Manfaat ekonomis dan ekologi daur ulang limbah kotoran ternak sapi menjadi kascing. Fakultas Kedokteran Hewan. IPB. Skripsi (1994). 
25. Wijaya KA. Nutrisi Tanaman sebagai Penentu Kualitas Hasil dan Resistensi Alami Tanaman. Prestasi Pustaka. Jakarta (2008).

26. Salisbury FB and dan CW Ross. Plant Physiology (Fisiologi Tumbuhan. alih bahasa: Diah R.L dan Sumaryono). ITB. Bandung (1995).

27. Jumin HB. Agronomi. Raja Grafindo Persada. Jakarta (2002).

28. Mahmoud EK and MM Ibrahim. "Effect of vermicompost and its mixtures with water treatment residuals on soil chemical properties and barley growth'. Journal of Soil Science and Plant Nutrition 12 (2012): 431- 440.

29. Hamim. "Underlaying drought stress effect on plant: Inhibition of photosynthesis". Journal of Biosciences 11 (2004): 164-169.

30. Harjadi S. Dasar-dasar Hortikultura. Departemen Budidaya Pertanian, Fakultas Pertanian. IPB. Bogor (1989).

31. Winaya D. Kesuburan Tanah dan Pemupukan. Fakultas Pertanian. Universitas Udayana. Bali (1993).

32. Rosmarkam., et al. Ilmu Kesuburan Tanah. Kanisius. Yogyakarta (2002).

33. Soepardi G. Sifat dan Ciri Tanah. IPB Pers. Bogor (1983).

34. Balai Penelitian Tanah., et al. Badan Penelitian dan Pengembangan Pertanian. Departemen Pertanian. Bogor. Jawa Barat (2009).

35. Tiwari SC., et al. "Microbial population, enzyme activities and nitrogen phosphorus potassium enrichment in eartworm cast and insurrounding soil of pineapple plantation". Biology and Fertility of Soil 8 (1989): 178-182.

\section{Assets from publication with us}

- Prompt Acknowledgement after receiving the article

- Thorough Double blinded peer review

- Rapid Publication

- Issue of Publication Certificate

- High visibility of your Published work

Website: www.actascientific.com/

Submit Article: www.actascientific.com/submission.php

Email us: editor@actascientific.com

Contact us: +919182824667 